Bulls.

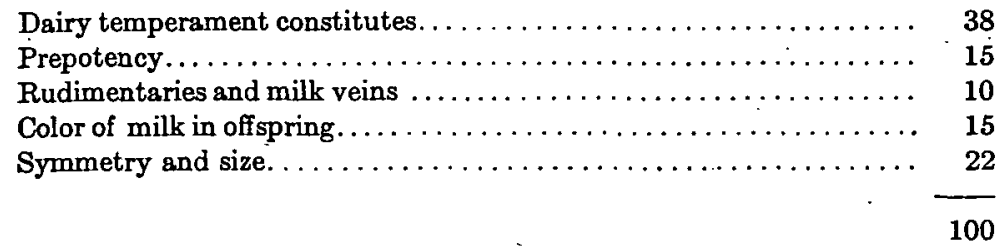

IN CONCLUSION.

Great as has been the growth of the Guernsey in popular favor and prosperous as has been her interests there is a sense of pride and satisfaction to those who have been associated with the breed that the ground she has gained has been won by her own honest efforts as a dairy cow. She has led by measuring her efforts by the critical test of a dairy cow what she can do in the year race, not what the butter maker might do with her products in short time trials. Records based on butter fat production for extended periods of time.

Returning the greatest amount for $\$ 1.00$ invested in food, making butter fat at least cost per pound, giving dairy products of the highest natural color and flavor, giving to the private estate that milk, cream and butter pleasing in appearance and excelling in usefulness, she and her grades being almost universally the favorites in the high class dairies of our large communities, such, friends, is the proud record of the Guernsey cow's advancement, and on such she appeals for recognition and support by the public.

\title{
THE ELIMINATION OF UNDESIRABLE VEGETABLE VARIETIES.
}

By Leonard H. VAUGHaN, Chicago, Ill.

The general vegetable planting public today has but a slight knowledge of the vast increase in the number of names of vegetables listed by different seedsmen throughout the world in the past score of years. If a numerical summary of every name of each vegetable listed were made, the sum total would be almost incredible. A few years ago the U.S. Department of Agriculture, Bureau of Plant Industry, published a bulletin on garden beans, describing in detail some 400 varieties and 185 types, synonyms included. This did not include the names of hundreds of varieties of foreign beans, or the names of varieties listed by obscure seedsmen. Since that time, the writer does not remember a single year that from ten to twenty entirely new names or varieties have 
not been added to the list by different seedsmen. Add to the bean list those of other vegetables almost or quite as lengthy, and the results can but be perplexity, confusion and disappointment to the planter. How many of all these varieties are really desirable for a private or a market garden? Perhaps two or three at the outside.

The various descriptions generally offered in seed lists are so meager, it is only by trial that a market gardener or private person can tell whether a variety is suitable for his needs, which makes it almost necessary for every.successful market gardener today, to have a trial ground, and even then with his limited knowledge of sources, and the present method of seed growing and seed selling, he is never sure that what he ordered last season, he will get the next.

The increase of varieties makes the work of the seed grower who supplies the seedsman, a very unhappy one, for the continually increasing list means more ground, more liability of mixture, and less attention to breeding. In looking over one wholesale seed grower's list, I find in bush and wax bush beans, sixty varieties, and this, of course, is only a limited list. To separate these fields, to prevent mixtures in threshing, harvesting and cleaning, to breed and select correctly, how complex and difficult the business must become.

The increase in number of varieties of vegetables causes a vast amount of substitution by both. seedsmen and growers, the argument being that if a customer orders certain old varieties, some new or similar sort may be sent because it is just as good or is really better. This results in a planter getting one thing one year, and another the next year if he or the seedsman happen to obtain their seeds from different growers. Substitution is one of the worst evils in the seed business. And yet it is sometimes a benefit when the man ordering old varieties knows nothing of the improved strains which afford better results. However, improved strains vary according to the grower, and on a standard variety, there are often many really different varieties being sold by different seedsmen.

To illustrate:-The Old Telephone pea is a large,l ight podded variety. Most growers today are sending on their Telephone orders, a dark podded pea, which may be the Alderman, Duke of Albany, Prince Edward, Admiral Dewey, or one of the other improved strains.

There are many reasons for a constant increase of names. Plant life varies continually, and it is almost impossible to keep some vegetables true to type first selected, unless ideals are kept constantly in mind. Earliness or color or shape is lost, etc. Prof. Bailey once made the remark that in five years after he introduced the Ignotum tomato, 
quite a famous tomato in its time, he procured seed from many different sources, and did not find one which was the Ignotum as he sent it out.

There is a continual call for new or improved varieties. Market gardeners are always endeavoring to have something better than their neighbors, and they think they can do this rather by planting a new kind than some old variety they have never tried. Market gardeners and many planters also have an inclination to experiment. They like to try new varieties. No one not in the seed business has any idea of the call for novelties, and how much a seed-house prides itself on being able to offer something new. The reason is evident. If a valuable new variety is added, the reputation it gives to a house is of extreme value. With all this call on the seedsman for new varieties, he must produce them. In fact, at the present date, it is more profitable for a seedsman to put out a new variety than to improve an old one. For he knows on old varieties he will have to compete with the price of just ordinary stock, while if he has something entirely new, he can ask his own price.

Planters unacquainted with the value of improved varieties continually call for old, displaced ones. An effort to substitute something else is looked upon with suspicion, hence many really obsolete varieties are listed by. seedsmen, not because they like to sell them, or make more money from such sales, but because their customers demand them.

There is another influence for the increase of names. When a seedsman finds that a certain new or old variety does especially well in his locality, he gives it a new name that competing seedsmen may be unable, without trial, to offer to his customers the same thing. He can then ask his customers who find this variety does well, good round prices without fear of competition. This is the reason attributed by several English seedsmen with whom the writer has talked, and accounts for the vast number of varieties of peas which it is necessary for an English wholesaler to keep regularly listed. Of course, everyone knows in the wholesale trade, just what varieties may be filled from the same bin, but the customers, English planters, buy under only their locality name, and hence locality seed trade is kept by the seedsman having these local varieties to sell.

Another reason for the constant increase of names, is the present ignorance of types and ideals by seed growers and seedsmen. It must be remembered that seeds are grown largely in only a few localities. Also that different varieties do their best under certain conditions. Now if we know only how certain varieties act in certain localities, how can we tell what is best in others, under different conditions? Obviously, only 
by experiment. Also, in different markets, the consumer only knows certain types of vegetables, and if improved types are offered, he refuses to buy until such knowledge is acquired. Ordinary market gardeners cannot afford to educate the buying public, hence, although there may be higher yielding and better quality vegetables, he can only grow with profit what that market knows.

Suppose growers knew what varieties were best suited for different localities,--what qualities, such as earliness, eating quality, productiveness, color, etc., etc., were best suited for different localities-things which could only be acquired by a vast amount of experimenting, the writer believes the varieties could be cut to one-fifth. The cutting of the varieties to one-fifth would mean a breeding of the standard varieties for crop uniformity in their desirable qualities. By having fewer varieties, much more attention could be brought to such breeding. Ideals known, the improved varieties before being offered would have to come up to certain qualifications which very few know now. I Ideal and uniform stocks would result in inestimable good, both for the producer and the consumer,--better quality and better yields produced at less cost.

Here is a suggestion for reducing the number of varieties now before the public.

Absolutely the first thing for eliminating the poorer varieties and redùcing the number to something in reason, would be an exact and accurate description of all the new existing sorts which seed growers might consider should be tried out. Then these varieties could at the same time, be classified with very few exceptions, into different well fixed types or sub-classes. Such work must necessarily be done with the coöperation and assistance of leading growers and seedsmen, and by a committee or number of persons whose final decisions would have weight and influence. After the types were decided upon and varieties classified experiments in different localities in the United States say, under the observation of horticultural experts of the different agricultural colleges and experiment stations, could determine just what ideals were best for particular sections, and which of the existing varieties best fulfilled those ideals. Planters would thus be informed what the best present varieties were for their needs, and breeders and seed growers would have definite knowledge, which they have not now, of what ideals to breed and select for.

To illustrate: Among the many types into which garden peas might be divided, are the extra early, round, smooth seeded varieties, some 
white seeded and some blue; these might be made into one or two types. Now consider some of the ideals of this type, which might be of benefit to different localities or different conditions in the same locality, which qualities or ideals are more or less guessed at by breeders today.

Earliness is the first requisite. A round seeded pea is not so sweet as a wrinkled pea, but is always more hardy and less liable to rot, and germinates much better in cold soil or during unfavorable weather, therefore, permits of early planting, besides being early maturing.

With earliness, there must be prolificacy. A variety a few days later than another, may be one-third better yielder; however, beinglater, the market gardener planting it might lose money in not securing the high early market price, which would more than offset the increased yieid obtained. The difference in yield and price probably would vary a great deal, according to market for which it is grown. Besides, a few days might bring the pea into competition with large podded, better quality peas, which, though decidedly light yielders, would, nevertheless, top the market and reduce the profit to the raiser of the prolific extra early.

Evenness in ripening is important, for a grower may then market his crop in one or two pickings, thus reducing to a minimum the harvesting expense, usually a large one.

The pods of some peas are larger and broader than others, making a much better appearance on the market, although, perhaps, they contain no great amount of peas.

Some varieties have darker colored pods than others. The darker podded peas are usually preferable, as they do not present such a wilted appearance after being picked a day or two, as do the lighter podded ones.

The canner uses a blue seeded extra early, because its appearance in the can is much handsomer than the white seeded variety.

The height of vine is another quality to be considered. The farmers who grow the seed want good vines that they may have fodder. A certain height of vine permits easy harvesting for the market grower, the canner and the seed grower.

Inherent qualities, such as hardiness, resistance to insects and fungus diseases, adaptibility to different soils, are other features which make the work complex.

These are only some of the points to be determined in judging the value of a variety. To do all this will require a vaśt amount of careful painstaking work; surely the results would justify it. The classification and description work would be considerably aided by the important and 
valuable work already done by the Department of Agriculture, Bureau of Plant Industry, whose bulletins on Lettuce and Bean varieties are the standard and best descriptions in the country today, and whose trials and reports on other vegetables might possibly be available.

The determining of the value of varieties in the various types would, of course, take time and some money. Perhaps some of the more important vegetable types could be worked out first, and at comparatively little expense.

Practically, the greatest $\operatorname{cog}$ in this suggested plan for the eliminating of the poorer varieties, would be the naming of the types and the best varieties under each type. Certain seedsmen have large advertising investments in some varieties, which, if discarded, would work considerable hardship for them. New improved varieties will have to be named; off-hand, one might say the introducer had the right to name such as he saw fit. Competitors are very loath, however, to list a vegetable with another firm's name attached, thus advertising a competitor in their own list or catalogue, besides, these new names are really what we are trying to avoid.

The plan outlined is, perhaps, entirely impracticable. Nothing has ever been done to reduce varieties, yet something should be done; whether on this line or on some other makes little difference. Who is to do it, is the question. Some growers in the American Seed Trade Association agitated the formation of a plan to reduce varieties, without anything coming of it. An appointed committee from this Association for the purpose of investigating a practical method of elimination of undesirable varieties, who would take up the matter with all interested parties, would greatly serve the welfare of the vegetable planters, breeders and seedsmen of America.

\section{RECENT ADVANCEMENT IN OUR KNOWLEDGE OF THE LAWS OF HEREDITY.}

By W. J. SpILlman, Washington, $D: C$.

A dozen years ago the subject of heredity was usually not taught in our colleges; we did not know enough to justify teaching it. Even yet the subject is rather poorly organized from a pedagogic standpoint, but there is plenty of subject matter for a strong college course. This matter is rapidly assuming form, and is even now, in some of our leading colleges, one of the most important and most popular biological courses. 